\title{
Molecular diagnosis and intraspecific genetic variability of root pathogens of arid legumes in Western Rajasthan, India
}

\author{
Ragini Gautam ${ }^{1}$, S. K. Singh ${ }^{1} \&$ Vinay Sharma ${ }^{2}$ \\ 1. Central Arid Zone Research Institute, Jodhpur- 342003, Rajasthan, India; tina_ragini@live.com, \\ sksingh1111@hotmail.com \\ 2. Department of Biosciences and Biotechnology, Banasthali Vidhyapeeth, Banasthali-304022, Rajasthan, India; \\ vinaysharma30@yahoo.co.uk
}

Received 26-II-2016. Corrected 03-VII-2016. $\quad$ Accepted 04-VIII-2016.

\begin{abstract}
The productivity of arid legumes, such as Clusterbean (Cyamopsis tetragonoloba), Cowpea (Vigna unguiculata), Moth bean (Vigna aconitifolia) and Horse gram (Macrotyloma uniflorum), may remain stagnant over decades because of their high susceptibility to root diseases. Besides, there is a limitation on the information about molecular diagnosis and intraspecific genetic variability of root pathogens in arid legumes. To contribute in this field, we assessed a total of 52 isolates from 88 root samples that were found infected with fungal pathogens in Jodhpur, Jaipur and Bikaner Districts of Rajasthan. Diseased roots samples were analyzed following standard microbiological methods for fungus extraction and purification, and for genetic studies. Irrespective of the geographical location from where the diseased samples were collected, all pathogen isolates were clustered in RAPD dendrograms as per their respective genera. Phylogram, based on multiple sequence alignment, revealed that different genera (i.e. Fusarium, Neocosmospora and Syncephalastrum), separated from each other, and species within the same genera, clustered together with their reference sequences with apreciable bootstrap values. Out of 20 representative isolates representing each cluster and all outgroups sequenced, eight were molecularly identified as Neocosmospora vasinfecta, five as Fusarium solani, two as Neocosmospora striata, two as Fusarium acutatum, one as Syncephalastrum monosporum, one as Fusarium oxysporum and one as Fusarium species. The root pathogens of the arid legumes were found neither restricted to a geographical location nor were host specific in nature. Fusarium solani wilt in cowpea and seedling rot in moth bean, $F$. oxysporum wilt in moth bean, F. acutatum damping off in cowpea and Clusterbean, Fusarium sp. seedling rot in Clusterbean, Neocosmospora striata root rot in cowpea and wilt in Clusterbean and Syncephalastrum monosporum root rot in Clusterbean were molecularly identified as new fungal records as pathogens causing root diseases in arid legumes. Rev. Biol. Trop. 64 (4): 1505-1518. Epub 2016 December 01.
\end{abstract}

Key words: RAPD, ITS, Fusarium, Neocosmospora, Syncephalastrum.

In India, arid legumes are grown in about 5 million hectares area with approximately 0.2 million tons production of grains annually. The major arid legumes are Clusterbean (Cyamopsis tetragonoloba), Cowpea (Vigna unguiculata), Moth bean (Vigna aconitifolia) and Horse gram (Macrotyloma uniflorum) which are predominantly grown in arid and semiarid tracks of Indian subcontinents. Due to inherent drought hardy characteristics arid legumes are mostly grown where land conditions are not suitable for cultivation of cereals mostly under rain fed conditions. During rainy season, high temperature coupled with moisture stress put them into abiotic and biotic stresses. Besides, blights, leaf spots, powdery mildews and viral diseases, these arid legumes are attacked by serious soil-borne pathogens with a very wide host range causing substantial damages and yield reduction in arid legumes. The information on molecular diagnosis and intraspecific genetic variability of root pathogens 
of arid legumes of the region is limited (Gautam, Singh, \& Sharma, 2013).

The most common diseases caused by these pathogens are charcoal rot (damping off), dry root rot, wilt, leaf blight and ashy stem blight. Efforts have been made to characterize the fungus populations in different parts of the world. This is based on its pathogenic variability, the morphological characteristics, as well as the molecular characteristics (Jana, Sharma, Prasad, \& Arora, 2003). Recently Random Amplified Polymorphic DNA (RAPD) and nuclear rDNA Internal Transcribed Spacer (ITS) polymorphism within Macrophomina phaseolina isolated from arid legumes of Western Rajasthan revealed genetic diversity among 33 isolates (Gautam et al., 2013). Species of Fusarium causes both major and minor diseases in these legumes (Aigbe \& Fawole, 2010).

The productivity of these arid legumes remains virtually stagnant over decades because of their susceptibility to root diseases. Most of the root pathogens are soil or seed borne, and colonize the xylem vessels by clogging and blocking completely to effect wilting. Accurate and rapid identification of pathogens is necessary for appropriate management of plant diseases (Narayanasamy, 2001).

The classical biological pathotyping techniques alone are not enough for a reliable identification and characterization of fungal pathotypes and population (Jamil et al., 2000). Therefore, present study was carried out to identify the cause of the disease (Koch's postulates), molecularly identify and characterize root pathogens of arid legumes using RAPD and ITS rDNA polymorphism to reveal inter and intra specific genetic relationships among and within root pathogens, to facilitate effective management of major diseases.

\section{MATERIALS AND METHODS}

Isolation of pathogens: Surveys were conducted to collect diseased plants of Clusterbean (Cyamopsis tetragonoloba), Cowpea (Vigna unguiculata), Moth bean (Vigna aconitifolia) and Horse gram (Macrotyloma uniflorum) from Jodhpur, Jaipur and Bikaner Districts of Rajasthan during the months of August and September, 2011. A total of 88 infected plants i.e., Clusterbean (38), Cowpea (16), Moth bean (24) and Horse gram (10) were collected, but this report only assessed those infections different from Macropomina phaseolina. To obtain pure cultures of root pathogens, these infected roots were cut into small pieces and surface sterilized using $5 \%$ sodium hypochlorite for three minutes, washed thrice in sterilized distilled water and air dried. Two or three infected root bits from each infected root sample were then aseptically transferred onto Petri plates containing PDA (39 g PDA, HiMedia Company) culture medium, containing $150 \mathrm{mg} /$ litre of streptomycin sulphate (to avoid bacterial contamination) and incubated in an incubator (Jindal, S.M. Scientific Instruments (P) Ltd, New Delhi, India) at $25 \pm 2{ }^{\circ} \mathrm{C}$ for five days. To raise pure cultures, the mycelia from the growing margins of each culture along with a piece of media from Petri plates were aseptically transferred into test tubes containing PDA, and incubated at $25 \pm 2{ }^{\circ} \mathrm{C}$ for a week. The 52 pure cultures obtained were stored at $4^{\circ} \mathrm{C}$ in a refrigerator until use.

Pathogenicity tests: Sandy loam soil was sterilized by autoclaving it (Apex, Conica Enterprises, New Delhi, India), at $121{ }^{\circ} \mathrm{C}$ for one hour. PVC plastic pots were filled with two $\mathrm{kg}$ of sterilized soil, and a pathogenecity test was set in a complete randomized block design, considering legumes origin and all 20 isolates: JD-HG10, JAI-CP11, JAI-CP16, JD-CB7, JD-CB9，BK-CB15，BK-CB17，BK-CB20, BK-CB26, JAI-CB37, JAI-MB22, JAI-MB24, BK-CB18，JD-CB10，BK-CB30，BK-CB22, JAI-CB34, JAI-CP13, JAI-CB36 and JAIMB21. Each isolated pathogen was raised in conical flasks on liquid Malt Extract Dextrose Broth culture medium (Malt Extract-10 g; Dextrose-5 $\mathrm{g}$ with antibacterial agent streptomycin $150 \mathrm{mg}$; 1 litre of sterilized distilled water) for 10 days. Conidial suspension was obtained by filtering mycelial mats and blending it with sterilized distilled water and again filtering it 
through two layers of sterile cheesecloth. Two week old plants of arid legumes i.e., clusterbean, cowpea, moth bean and horse gram, were then inoculated with conidial suspension of specified isolate (from which it was originally isolated) at the base by disturbing the soil. The inoculated plants were incubated in green house under high temperature $\left(28-30^{\circ} \mathrm{C}\right)$ and moisture stress conditions $(100 \mathrm{~mL}$ water every $4^{\text {th }}$ day and humidity $60-70 \%$ ) to facilitate disease development. A total of five pots were inoculated with each isolate. Plant symptoms were recorded and the pathogen reisolated. Besides, upon microscopic examination, the pathogenicity of each isolated pathogen was confirmed. Identifications to genus level were carried following Barnett and Hunter (1990).

DNA isolation: For DNA isolation, a small piece of growing mycelia from each of the 52 isolated cultures was aseptically transferred to separate Malt Extract Dextrose Broth culture medium and incubated in a BOD incubator at $25 \pm 2{ }^{\circ} \mathrm{C}$ for seven days. The fungal mycelial net from each raised pure culture was filtered using filter paper through funnel. The genomic DNA was extracted from approximately $100 \mathrm{mg}$ of fresh mycelium by crushing it in conical micro centrifuge tubes using micropestles in liquid nitrogen. The HiPura kit of HiMedia Company and protocols suggested by Birren and Lai (1993), Sambrook, Fritsch and Maniatis (1989) were followed for genomic DNA isolation. Finally, the DNA was eluted in $200 \mu \mathrm{L}$ of Tris EDTA buffer (TE buffer).

RAPD analysis: Eighteen decamer random primers of OPA, OPB and OPP series (Operon Technologies, USA: http://www.operon.com) were used for initial screening of all the isolates. Finally, the data of ten RAPD primers exhibiting consistent reproducible amplified products on gel electrophoresis were used for DNA fingerprinting. Each PCR was performed in a total reaction mixture of $25 \mu \mathrm{L}$ following Gautam et al. (2013). Amplicons were separated on $1.5 \%$ agarose gel (Sigma) pre-stained with ethidium bromide solution using $1 \times$ TAE (Tris Acetic acid EDTA, Himedia) buffer. The gel was run for $3 \mathrm{~h}$ at $50 \mathrm{~V}$ and the RAPD amplicons profiles were recorded using Syngene Gel Documentation System with Genesnap software. The size of amplified fragments was determined using $100 \mathrm{bp}$ plus ladder (MBI Fermentas). All RAPD reactions were performed twice to test the reproducibility of the amplicons profile.

Internal transcribed spacer (ITS) amplification: The universal primers ITS- 1 ( 5 ' TCC GTA GGT GAA CCT GCG G 3') and ITS-4 (5' TCC TCC GCT TAT TGA TAT GC 3') were used for the amplification of ITS-1-5.8S-ITS-4 region. Each PCR amplification was performed in a total volume of $50 \mu \mathrm{L}$ following Gautam et al. (2013). Amplified ITS regions were sequenced employing ABI Prism DNA sequencer (Applied Biosystems, Carlsbad, CA, USA) using ITS-1 and ITS-4 primers separately for DNA labeling by the BigDye terminator method (Applied Biosystems, Foster City, CA, USA). Molecular identification of each fungal isolate was done on the basis of similarity with the best aligned sequence of BLAST search and accordingly species designated.

Molecular data analysis: The RAPD amplification products were scored as present (1) and absent (0) of scorable loci for each primer isolate combinations. Molecular data were entered into a binomial matrix and were used to determine Jaccard's similarity coefficient with NTSYS-pc software (Rohlf, 1997).

To perform analysis of molecular variance (AMOVA), the 52 isolates of root pathogens from arid legumes were divided into four populations based on the arid legume crop from which they were isolated i.e., population one (clusterbean), population two (horse gram), population three (cowpea) and population four (moth bean). Principal Component Analysis (PCA) via covariance matrix was calculated using GenALEx 6 software. Whereas, diversity in the frequency of fragment size of RAPD patterns was apportioned within and among root pathogen isolates using Shannon's information 
index $(i)$ and gene diversity index $(h)$ following using PopGen 32 programme.

The multiple sequence alignment of ITS region (ITS-1, 5.8S r-RNA gene and ITS-2) of all the 20 representative root pathogen isolates was performed using ClustalX 2.0.11 software. The phylogenetic relationships of root rot pathogens were established by multiple alignment of sequences and generating phylogram depicting bootstrap values using NJ plot software based on Single Nucleotide Polymorphisms (SNPs), insertions/deletions (INDELS), and or length diversity in the ITS and 5.8S nuclear rDNA regions. To assess the robustness of phylogenetic relationships, the best aligned reference sequence representing of each species from GenBank database was downloaded in fasta format. A composite phylogenetic tree with bootstrap values showing grouping of 20 isolates sequenced with 11 reference sequences was generated to measure phylogenetic accuracy.

\section{RESULTS}

Isolation tests results: All the four steps of Koch's postulates were successfully completed for each test pathogen in a replicated trial. The details of fungal isolates, host, district and colony characteristics are shown at table 1. A total of 52 root samples were found infected with fungal pathogens belonging to genus Fusarium, Neocosmospora and Syncephalastrum. In all, four types of colony and growth patterns i.e. feathery, dense, fluffy and restricted, were recorded from different isolates. Similarly disease symptoms from seedling wilt (damping off) to seedling rot, wilt and root rot were recorded. Light pink to dark red pigmentations were also recorded in different cultures. Based on microscopic examinations, genus level identifications revealed that from the total of 52 diseased root samples considered in this study, 26 samples were identified as Neocosmospora, 25 as Fusarium and 1 as Syncephalastrum.
RAPD analysis: Out of 18 decamer random primers, 10 primers detected intraspecific variations generating scorable amplicons and reproducible patterns that have generated 147 marker bands in the range of $250 \mathrm{bp}$ to 5000 bp. Of which, 146 marker bands were polymorphic amounting to $99.41 \%$ polymorphism ranging from $94.11 \%$ to $100 \%$. The number of PCR amplified products ranged from 11 (OPP16) to 18 (OPB-04) with an average of about 14.7 bands/primer (Table 2). The PIC values varied from $84 \%$ to $92 \%$ with an average of $90 \%$. The primer OPB-06 and OPB-14 exhibited the maximum PIC value of $92 \%$ which was closely followed by OPA-09, OPA-13 and OPB-05 with $91 \%$. A representative RAPD profile generated using OPB-06 exhibiting the maximum PIC value is shown vide figure. 1A, figure $1 \mathrm{~B}$ and figure $1 \mathrm{C}$.

A cumulative RAPD dendrogram delineated all the 52 isolates into sub-clusters ranging from 32 to $95 \%$ similarity. In all, the isolates can be seen in eight distinct clusters and seven isolates as out groups to these clusters (Fig. 2). Cluster one included two, cluster two contained nine, cluster three compiled 10 , cluster four comprised seven, cluster five included six, cluster six and seven comprised four isolates each, and cluster eight compiled of three isolates.

Irrespective of the geographical location from where the diseased samples were collected, all isolates belonging to the genus Neocosmospora, aligned from cluster one to cluster five including all outgroups between these clusters. Whereas, all isolates of genus Fusarium converged into cluster six to eight and flanking outgroups including one isolate of Syncephalastrum.

ITS amplification: Based on the clustering patterns of different isolates of root pathogens of arid legumes, 20 representative isolates from all RAPD clusters and distinct isolates were selected for nuclear rDNA ITS region sequencing. All the isolates generated 
TABLE 1

Morphological characterization of fungal pathogens causing root diseases in arid legumes

\begin{tabular}{|c|c|c|c|c|c|c|c|c|}
\hline S. No. & Isolate & Host & District & $\begin{array}{c}\text { Colony } \\
\text { Growth Pattern }\end{array}$ & Colony Colour & $\begin{array}{l}\text { Pigmentation } \\
\text { in medium }\end{array}$ & Genus & Disease Symptom \\
\hline 1. & JD-CB7 & Clusterbean & Jodhpur & Feathery & Off White & Light Pink & Neocosmospora & Wilt NV \\
\hline 2. & JD-CB8 & Clusterbean & Jodhpur & Feathery & Off White & Light Pink & Neocosmospora & Wilt \\
\hline 3. & JD-CB9 & Clusterbean & Jodhpur & Restricted & Light Purple & Dark Pink & Neocosmospora & Wilt NS \\
\hline 4. & JD-CB10 & Clusterbean & Jodhpur & Restricted & Off White & Light Pink & Neocosmospora & Wilt NV \\
\hline 5. & JD-CB11 & Clusterbean & Jodhpur & Restricted & Off White & Light Pink & Neocosmospora & Damping off \\
\hline 6. & JD-CB12 & Clusterbean & Jodhpur & Dense & Off White & Light Pink & Neocosmospora & Wilt \\
\hline 7. & JD-CB13 & Clusterbean & Jodhpur & Fluffy & Off White & Light Pink & Neocosmospora & Wilt \\
\hline 8. & JD-CB14 & Clusterbean & Jodhpur & Dense & Off White & Light Pink & Neocosmospora & Wilt \\
\hline 9. & JD-HG9 & Horse gram & Jodhpur & Dense & Off White & Light Pink & Neocosmospora & Wilt \\
\hline 10. & JD-HG10 & Horse gram & Jodhpur & Restricted & Off White & Light Pink & Neocosmospora & Wilt NV \\
\hline 11. & JD-CP9 & Cowpea & Jodhpur & Dense & Light Pink & Dark Pink & Neocosmospora & Wilt \\
\hline 12. & JD-MB14 & Moth bean & Jodhpur & Feathery & Dark Pink & Dark Pink & Neocosmospora & Wilt \\
\hline 13. & JD-MB15 & Moth bean & Jodhpur & Feathery & Off White & Light Pink & Neocosmospora & Wilt \\
\hline 14. & BK-CP10 & Cowpea & Bikaner & Feathery & Off White & Dark Pink & Neocosmospora & Seedling rot \\
\hline 15. & BK-MB16 & Moth bean & Bikaner & Restricted & Dark Pink & Dark Pink & Neocosmospora & Wilt \\
\hline 16. & BK-MB17 & Moth bean & Bikaner & Fluffy & Dark Pink & Light Pink & Neocosmospora & Wilt \\
\hline 17. & BK-MB18 & Moth bean & Bikaner & Fluffy & Off White & Light Pink & Neocosmospora & Seedling rot \\
\hline 18. & BK-CB15 & Clusterbean & Bikaner & Dense & Off White & Dark Pink & Syncephalastrum & Root rot SM \\
\hline 19. & BK-CB16 & Clusterbean & Bikaner & Restricted & Off White & Light Pink & Neocosmospora & Wilt \\
\hline 20. & BK-CB17 & Clusterbean & Bikaner & Restricted & Light Pink & Light Pink & Neocosmospora & Wilt NV \\
\hline 21. & BK-CB18 & Clusterbean & Bikaner & Feathery & Off White & Dark Red & Neocosmospora & Wilt NV \\
\hline 22. & BK-CB19 & Clusterbean & Bikaner & Fluffy & Off White & Light Red & Neocosmospora & Wilt \\
\hline 23. & BK-CB20 & Clusterbean & Bikaner & Restricted & Off White & Light Pink & Fusarium & Wilt FS \\
\hline 24. & BK-CB21 & Clusterbean & Bikaner & Fluffy & Pink & Light Red & Neocosmospora & Root rot \\
\hline 25. & BK-CB22 & Clusterbean & Bikaner & Restricted & Off White & Light Red & Neocosmospora & Root rot \\
\hline 26. & BK-CB23 & Clusterbean & Bikaner & Restricted & Pink & Light Red & Fusarium & Wilt NV \\
\hline 27. & BK-CB24 & Clusterbean & Bikaner & Dense & Off White & Light Red & Fusarium & Wilt \\
\hline 28. & BK-CB25 & Clusterbean & Bikaner & Dense & Off White & Light Red & Fusarium & Wilt \\
\hline 29. & BK-CB26 & Clusterbean & Bikaner & Restricted & Light Pink & Light Red & Fusarium & Damping off FA \\
\hline 30. & BK-CB27 & Clusterbean & Bikaner & Restricted & Off White & Dark Pink & Fusarium & Damping off \\
\hline 31. & BK-CB28 & Clusterbean & Bikaner & Restricted & Off White & Dark Pink & Fusarium & Damping off \\
\hline 32. & BK-CB29 & Clusterbean & Bikaner & Restricted & Off White & Dark Pink & Fusarium & Root rot \\
\hline 33. & BK-CB30 & Clusterbean & Bikaner & Dense & Off White & Dark Pink & Neocosmospora & Root rot NV \\
\hline 34. & JAI-CP11 & Cowpea & Jaipur & Restricted & Light Pink & Dark Pink & Neocosmospora & Root rot \\
\hline 35. & JAI-CP12 & Cowpea & Jaipur & Feathery & Off White & Light Pink & Fusarium & Wilt \\
\hline 36. & JAI-CP13 & Cowpea & Jaipur & Feathery & Off White & Light Pink & Fusarium & Wilt FS \\
\hline 37. & JAI-CP14 & Cowpea & Jaipur & Feathery & Off White & Light Pink & Fusarium & Wilt \\
\hline 38. & JAI-CP15 & Cowpea & Jaipur & Feathery & Off White & Light Pink & Fusarium & Wilt \\
\hline 39. & JAI-CP16 & Cowpea & Jaipur & Dense & Off White & Light Red & Fusarium & Damping off FA \\
\hline 40. & JAI-MB19 & Moth bean & Jaipur & Feathery & Pink & Dark Red & Fusarium & Wilt \\
\hline 41. & JAI-MB20 & Moth bean & Jaipur & Fluffy & Off White & Dark Red & Fusarium & Wilt \\
\hline 42. & JAI-MB21 & Moth bean & Jaipur & Fluffy & Dark pink & Light Pink & Fusarium & Seedling rot FS \\
\hline 43. & JAI-MB22 & Moth bean & Jaipur & Dense & Purple & Dark Red & Fusarium & Wilt F OX \\
\hline 44. & JAI-MB24 & Moth bean & Jaipur & Dense & Pink & Light Red & Fusarium & Wilt \\
\hline 45. & JAI-CB31 & Clusterbean & Jaipur & Dense & Off White & Light Red & Fusarium & Wilt \\
\hline 46. & JAI-CB32 & Clusterbean & Jaipur & Dense & Off White & Light Red & Fusarium & Wilt \\
\hline 47. & JAI-CB33 & Clusterbean & Jaipur & Restricted & Pink & Light Red & Fusarium & Wilt \\
\hline 48. & JAI-CB34 & Clusterbean & Jaipur & Restricted & Off White & Light Pink & Neocosmospora & Seedling rot NV \\
\hline 49. & JAI-CB35 & Clusterbean & Jaipur & Restricted & Off White & Dark Red & Fusarium & Wilt \\
\hline 50. & JAI-CB36 & Clusterbean & Jaipur & Dense & Off White & Dark Red & Fusarium & Wilt FS \\
\hline 51. & JAI-CB37 & Clusterbean & Jaipur & Dense & Off White & Light Pink & Fusarium & Seedling rot F Sp \\
\hline 52. & JAI-CB38 & Clusterbean & Jaipur & Dense & Off White & Dark Red & Fusarium & Wilt \\
\hline
\end{tabular}

JD, Jodhpur, BK, Bikaner, JAI, Jaipur, CB, clusterbean, CP, cowpea, MB, moth bean, HG, Horse gram, NV, Neocosmospora vasinfecta, FS, Fusarium solani, FOX, Fusarium oxysporum, FA, Fusarium acutatum, SM, Syncephalastrum monosporum, NS, Neocosmospora striata. 
TABLE 2

Details of primer code, GC content, per cent polymorphism and PIC values of RAPD primers

\begin{tabular}{|c|c|c|c|c|c|c|c|}
\hline S.N. & Primer Code & Primer Sequence & GC (\%) & $\begin{array}{l}\text { No. of } \\
\text { Bands }\end{array}$ & $\begin{array}{c}\text { No. of } \\
\text { Polymorphic bands }\end{array}$ & $\begin{array}{c}\text { Polymorphism } \\
(\%)\end{array}$ & PIC Values \\
\hline 1. & OPA-02 & TGC CGA GCT G & 70 & 13 & 13 & 100 & $90 \%$ \\
\hline 2. & OPA-09 & GGG TAA CGC C & 70 & 15 & 15 & 100 & $91 \%$ \\
\hline 3. & OPA-13 & CAG CAC CCA C & 70 & 13 & 13 & 100 & $91 \%$ \\
\hline 4. & OPB-04 & GGA CTG GAG T & 60 & 18 & 18 & 100 & $90 \%$ \\
\hline 5. & OPB-05 & TGC GCC CTT C & 70 & 12 & 12 & 100 & $91 \%$ \\
\hline 6. & OPB-06 & TGC TCT GCC C & 70 & 17 & 16 & 94.11 & $92 \%$ \\
\hline 7. & OPB-10 & CTG CTG GGA C & 70 & 16 & 16 & 100 & $90 \%$ \\
\hline 8. & OPB-13 & TTC CCC CGC T & 70 & 14 & 14 & 100 & $89 \%$ \\
\hline 9. & OPB-14 & TCC GCT CTG G & 70 & 18 & 18 & 100 & $92 \%$ \\
\hline \multirow[t]{3}{*}{10.} & OPP-16 & CCA AGC TGC C & 70 & 11 & 11 & 100 & $84 \%$ \\
\hline & Total & & & 147 & 146 & & \\
\hline & Average & & & & & 99.41 & 90.00 \\
\hline
\end{tabular}
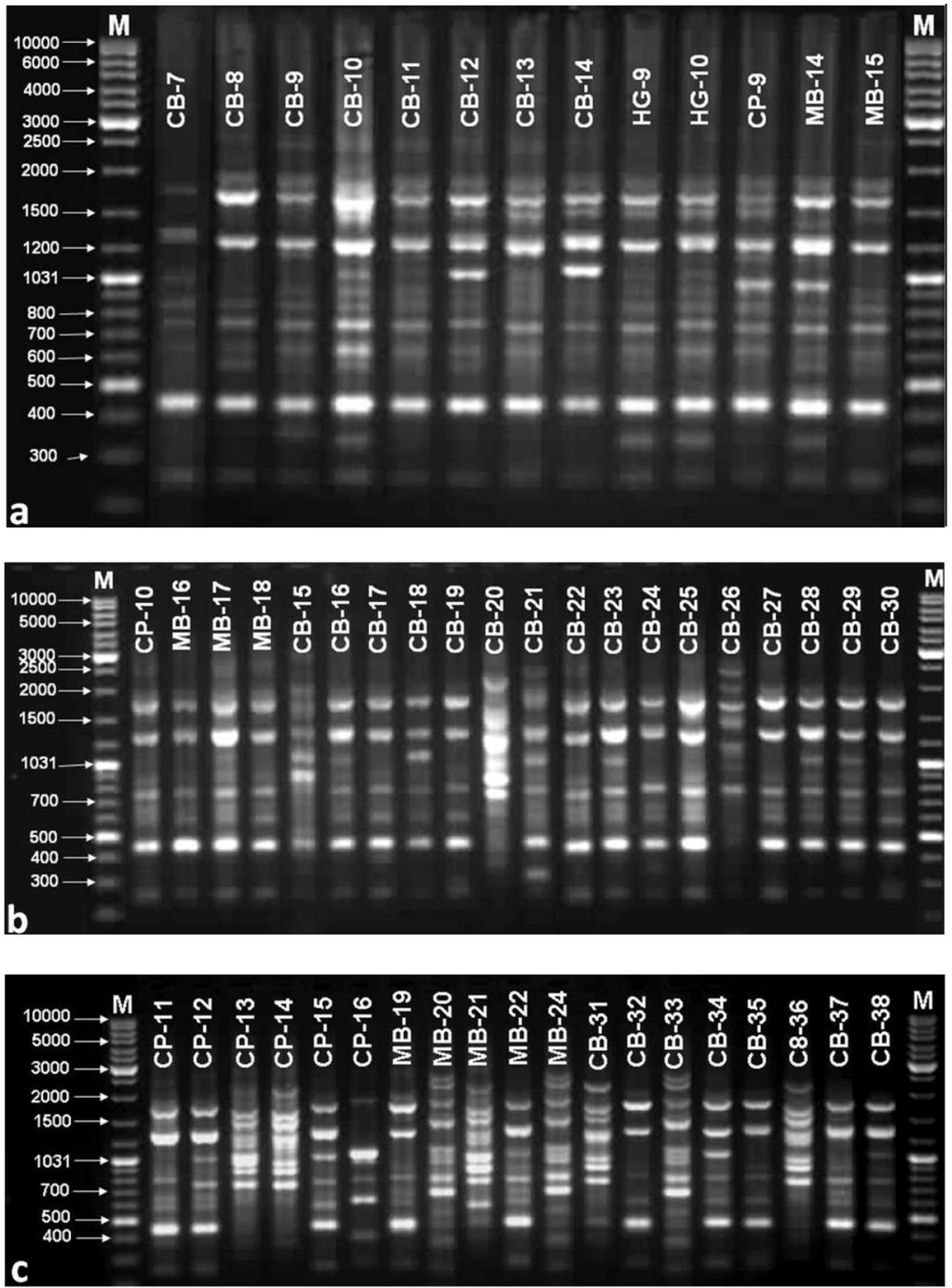

Fig. 1(A,B,C). RAPD profiles of root pathogens amplified by OPB-06 primer (a) Jodhpur, (b) Bikaner and (c) Jaipur. 


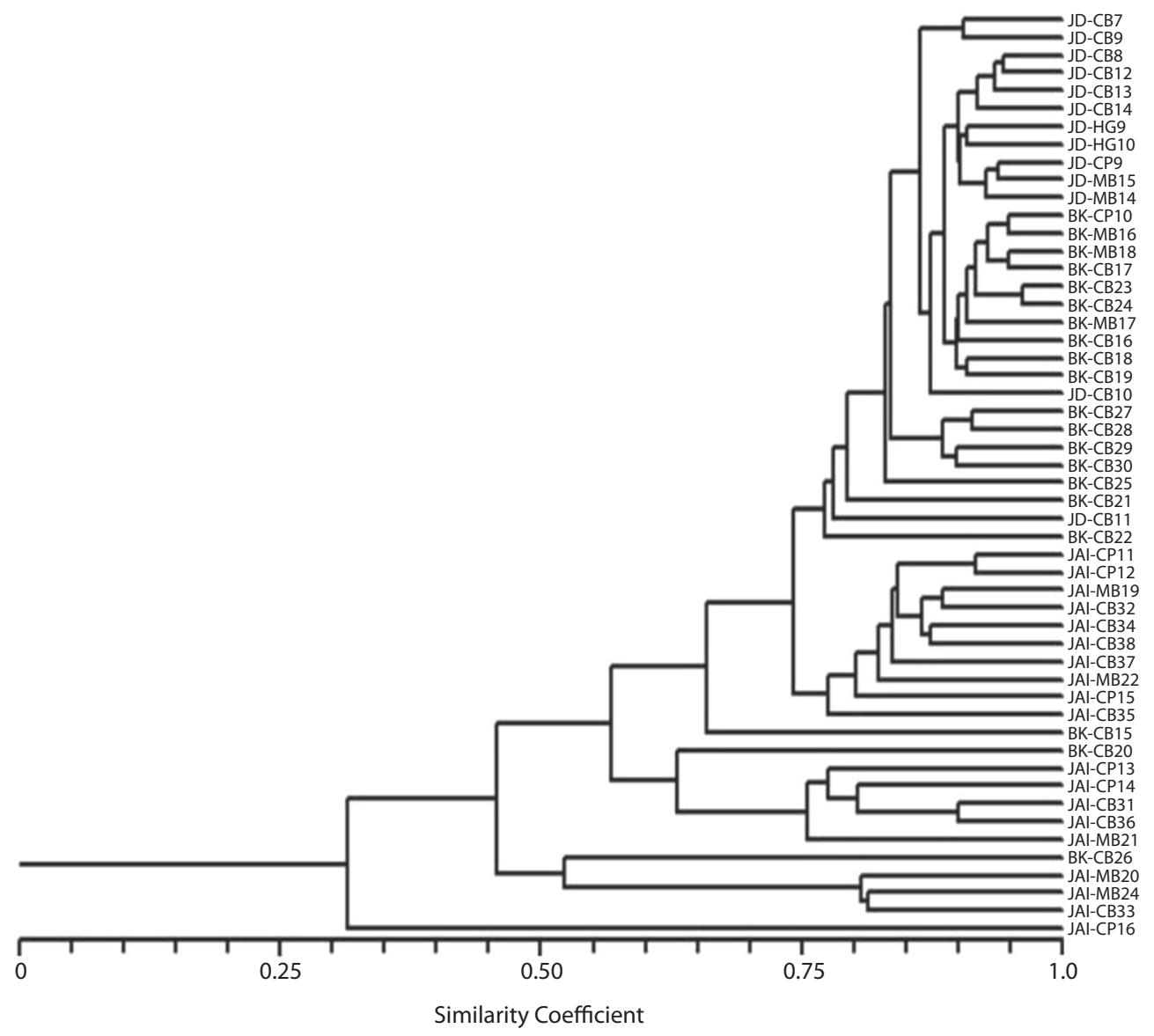

Fig. 2. Dendrogram of 52 isolates of root pathogens based on 10 RAPD informative primers.

a single prominent band on agarose gel which included partial sequence of $18 \mathrm{~S}$ gene, complete sequence of ITS-1, 5.8S gene, ITS-2 and partial sequence of $28 \mathrm{~S}$ gene. The nucleotide sequences were subjected to BLAST search using NCBI, USA databases. The species level designation were assigned to each isolate considering the maximum identities with that of available reference sequences of NCBI databases (Table 3).

Molecular data analysis: The novel gene sequences were submitted to NCBI and gene bank accession numbers obtained. In order to detect SNP's, insertions and deletions
(INDELS) and total length polymorphism of rDNA region, all the isolates were subjected to multiple sequence alignment using clustal $\mathrm{X}$ software programme. A phylogram was generated using tree view software and boot strap values determined using $\mathrm{NJ}$ plot programme (Fig. 3) to validate the species designation and to reveal the nucleotide polymorphism vis-à-vis reference sequence available in NCBI databases. The best aligned reference sequences were also downloaded and subjected to multiple sequence alignment to establish lineages. It is clear from the phylogram that different genera (i.e. Fusarium, Neocosmospora and Syncephalastrum) separated from each other and species 
TABLE 3

Nucleotide base pair lengths of nuclear ribosomal RNA gene of representative genotypes of RAPD sub-clusters Red Culture

\begin{tabular}{|c|c|c|c|c|c|c|c|}
\hline S. N. & Isolate & Molecular identification & $\begin{array}{c}\text { Gen accession } \\
\text { number }\end{array}$ & $\begin{array}{l}\text { ITS-1 } \\
\text { (bp) }\end{array}$ & $\begin{array}{l}5.8 \mathrm{~S} \\
(\mathrm{bp})\end{array}$ & $\begin{array}{l}\text { ITS-2 } \\
\text { (bp) }\end{array}$ & $\begin{array}{l}\text { Total } \\
\text { (bp) }\end{array}$ \\
\hline 1. & JD-HG10 & Neocosmospora vasinfecta & JQ954881 & 149 & 167 & 156 & 472 \\
\hline 2. & JAI-CP11 & Neocosmospora striata & JQ954882 & 148 & 156 & 171 & 475 \\
\hline 3. & JAI-CP16 & Fusarium acutatum & JQ954883 & 148 & 156 & 167 & 471 \\
\hline 4. & JD-CB7 & Neocosmospora vasinfecta & JQ954884 & 150 & 166 & 158 & 474 \\
\hline 5. & JD-CB9 & Neocosmospora striata & JQ954885 & 149 & 158 & 165 & 472 \\
\hline 6. & BK-CB15 & Syncephalastrum monosporum & JQ954886 & 192 & 150 & 200 & 542 \\
\hline 7. & BK-CB17 & Neocosmospora vasinfecta & JQ954887 & 148 & 156 & 171 & 475 \\
\hline 8. & BK-CB20 & Fusarium solani & JQ954888 & 148 & 157 & 173 & 478 \\
\hline 9. & BK-CB26 & Fusarium acutatum & JQ954889 & 148 & 158 & 166 & 472 \\
\hline 10. & JAI-CB37 & Fusarium sp. & JQ954890 & 112 & 158 & 170 & 440 \\
\hline 11. & JAI-MB22 & Fusarium solani & JQ954891 & 148 & 157 & 173 & 478 \\
\hline 12. & JAI-MB24 & Fusarium oxysporum & JQ954892 & 132 & 162 & 156 & 450 \\
\hline 13. & BK-CB18 & Neocosmospora vasinfecta & JX517195 & 150 & 158 & 165 & 473 \\
\hline 14. & JD-CB10 & Neocosmospora vasinfecta & JX517196 & 149 & 158 & 165 & 472 \\
\hline 15. & BK-CB30 & Neocosmospora vasinfecta & JX517197 & 149 & 158 & 165 & 472 \\
\hline 16. & BK-CB22 & Neocosmospora vasinfecta & JX517198 & 150 & 158 & 165 & 473 \\
\hline 17. & JAI-CB34 & Neocosmospora vasinfecta & JX517199 & 149 & 158 & 165 & 472 \\
\hline 18. & JAI-CP13 & Fusarium solani & JX517200 & 150 & 158 & 172 & 480 \\
\hline 19. & JAI-CB36 & Fusarium solani & JX517201 & 150 & 158 & 172 & 480 \\
\hline 20. & JAI-MB21 & Fusarium solani & JX517202 & 150 & 158 & 172 & 480 \\
\hline
\end{tabular}

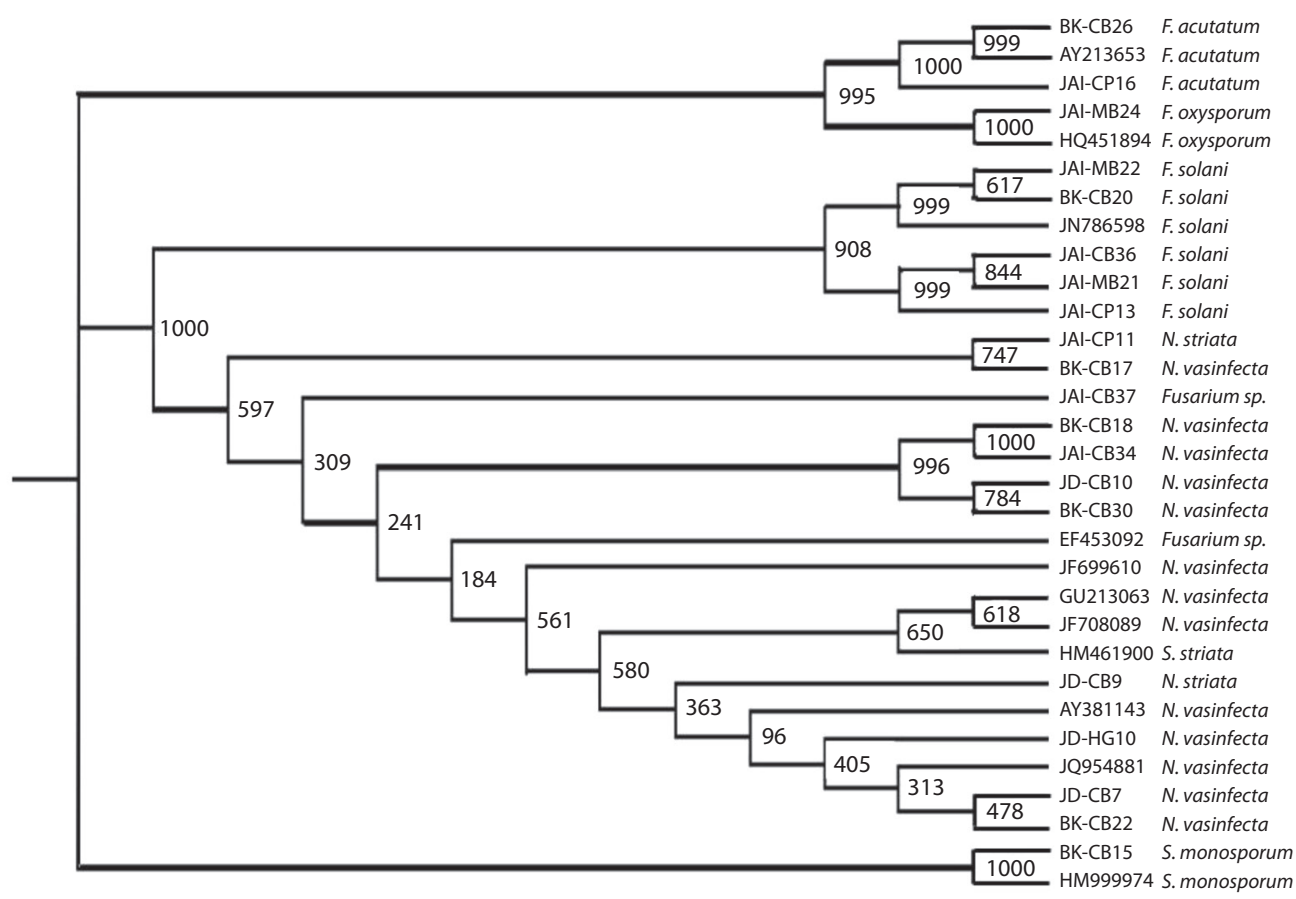

Fig. 3. Phylogram generated using Tree View of multiple sequences aligned rDNA region of 20 root pathogen isolates along with reference sequences. 
TABLE 4

Summary of genetic variation statistics for all loci

\begin{tabular}{cccccc} 
Locus (mean) & Sample Size & $n a$ & $n e$ & $h$ & $i$ \\
Pop 1 & 32 & 1.9660 & 1.5273 & 0.3066 & 0.4627 \\
Pop 2 & 2 & 1.0952 & 1.0673 & 0.0394 & 0.0576 \\
Pop 3 & 8 & 1.8299 & 1.5045 & 0.2930 & 0.4378 \\
Pop 4 & 10 & 1.8299 & 1.5543 & 0.3087 & 0.4539 \\
Mean of all loci & 52 & 2.0000 & 1.5427 & 0.3129 & 0.4712 \\
\hline
\end{tabular}

$n a$, observed number of alleles, $n e$, effective number of alleles, $h$, Nei's gene diversity, $i$ Shannon information index.

TABLE 5

Matrix of unbiased genetic identity and genetic distance according to Nei (1973) among 4 populations of root pathogens based on RAPD markers

\begin{tabular}{ccccc} 
Population & Pop 1 & Pop 2 & Pop 3 & Pop 4 \\
Pop1 & $* * * *$ & 0.8860 & 0.9840 & 0.9972 \\
Pop2 & 0.1210 & $* * * *$ & 0.8273 & 0.8766 \\
Pop3 & 0.0161 & 0.1896 & $* * * *$ & 0.9796 \\
Pop4 & 0.0029 & 0.1317 & 0.0206 & $* * * *$ \\
\hline
\end{tabular}

Nei’s genetic identity (above diagonal) and genetic distance (below diagonal).

within the genera converged together and grouped with respective reference sequences with appreciable bootstrap values.

Out of 20 isolates, eight were molecularly identified as Neocosmospora vasinfecta, five as Fusarium solani, two as Neocosmospora striata, two as Fusarium acutatum, one as Syncephalastrum monosporum, one as Fusarium oxysporum and one as Fusarium species. AMOVA revealed $100 \%$ variation within population of root rot pathogens isolated from arid legumes. All the four populations of arid legumes, root pathogens were subjected to PCA using GenaLX. The first three principle coordinates accounted for 44.74, 17.78 and 15.03 respective amounting to a total of 77.55 $\%$ of total variance. The eigen vector analysis indicated that the contribution of the first three factors were 38.2, 15.2 and 12.8 respectively explaining a total of $66.2 \%$ of total variability. The analysis of RAPD binary data using Popgene revealed that the coefficient of gene differentiation between populations (Gst) was 2.0170 among all the populations. The genetic analysis of RAPD data of all the 52 isolates of root pathogens isolated were performed by dividing the isolates on the basis of host from which they were initially isolated. For example, population one (32 isolates of Clusterbean), population two (two isolates of horse gram), population three (eight isolates of cow pea), and population four (10 isolates of moth bean).

The summary of genetic variation statistics of all loci is presented in table 4. The mean values of all the four populations together for Nei's genetic diversity $(h)$ was 0.3129 and Shannon information index (i) was 0.4712 . The data revealed that the genetic diversity of root pathogen isolates of population four (moth bean) was the richest among all the four populations. The matrix of unbiased genetic identity and distance among four populations of root pathogens based on RAPD markers is presented in table 5. The Nei's genetic distance ranged from 0.0029 to 0.1896 and the genetic identity ranged from 0.8273 to 0.9972 . The largest distance was recorded between population two (horse gram) and three (cowpea) and the least between the population one (Clusterbean) and population four (moth bean). 


\section{DISCUSSION}

Besides dry root rot caused by Macrophomina phaseolina (Gautam et al., 2013), 52 root samples were found infected with fungal pathogens. Irrespective of the geographical location from where the diseased samples were collected, all pathogen isolates clustered in RAPD dendrogram as per their respective genera. An insight of morphological characters and RAPD dendrogram revealed no consistency in grouping root pathogen isolates as morphologically similar isolates were genetically cataloged into different RAPD clusters. For instance, $N$. vasinfecta isolates with identical morphological characters such as restricted colony growth pattern, off white colony color and light pink pigmentation in the culture medium were genetically cataloged into distinct RAPD clusters i.e. JD-HG10 (cluster two), JAI-CB34 (cluster five) and JD-CB10 as out group between clusters three and four. Similarly, the phylogenetic clustering of isolates was also not in accordance with the host from which they were isolated. The isolates belonging to different hosts were well distributed among different RAPD phylogenetic clusters. For example, isolates from Bikaner aligned in cluster three, four and between cluster four and five, six and seven and seven and eight clusters as out groups.

The results indicated that the measures of relative genetic distances among populations did not completely correlate the geographical distances of places of their isolations and or hosts suggesting that the root pathogens of the arid legumes are neither confined to a geographical location and or are host specific in nature. Present results are in agreement with earlier molecular studies suggesting that grouping of Macrophomina phaseolina isolates independent of host and geography (Gautam et al., 2013) and DNA polymorphism in Fusarium spp. failed to show a positive correlation with geographical origin (Gargouri, Bernier, Hajlaoui, \& Marrakchi, 2003) performed genotyping with RAPD markers resolves pathotype diversity in the ascochyta blight and Fusarium wilt pathogens of chickpea in Pakistan. By contrast, they reported different levels of virulence among $F$. oxysporum f. sp. ciceri collected from different geographical locations.

RAPD technique has been used for the characterization of the microbes and detection of microbial diversity (Gautam et al., 2013; Sharma, Verma, \& Sharma, 2013). Under present study, RAPD revealed high levels of polymorphism among root pathogens coupled with higher PIC percentage due to discretionary ability of selective primers in evaluating genetic diversity of root pathogens in arid legumes. Further genus wise RAPD clustering and alignment of isolates belonging to the genus Neocosmospora from cluster 1 to 5 including all outgroups between these clusters and Fusarium isolates aggregating from cluster 6 to 8 and flanking outgroups including one isolate of Syncephalastrum revealed both inter and intraspecific genetic diversity among root pathogen isolates.

Fusarium taxonomy and species designation based on morphological characterization is most frustrating (Brayford, 1989). More than 120 different formae speciales of $F$. oxysporum have been identified based on specificity to host species belonging to a wide range of plant families some formae speciales are not primarily vascular pathogens but cause foot and root rot or bulb rot (Pietro, Madrid, Caracuel, Jarana, \& Roncero, 2003).

Riveros, Munoz, Gonzalez, Rojas and Hinrichsen (2001) compared RAPD-PCR with classical taxonomy, morphology, pathogenecity of Fusarium strains and found that the obtained results were inconsistent. Different workers (Jana et al., 2003; Ibrahim \& Nirenberg, 2000) have grouped Fusarium spp. population from different plant host by using RAPD analysis and suggested that RAPD markers can be a quick and reliable alternative for differentiating isolates of Fusarium spp.

A high degree of nucleotide variations in the nuclear rDNA ITS region allowed separation of 20 representative isolates of all RAPD clusters and distinct isolates and of which eight were molecularly identified as $N$. vasinfecta, five as $F$. solani, two as $N$. striata, 
two as F. acutatum, one as Syncephalastrum monosporum, one as $F$. oxysporum and one as Fusarium species. Due to SNP's, insertions and deletions (INDELS) and total length polymorphism of rDNA region, upon multiple sequence alignment different genera (i.e. Fusarium, Neocosmospora and Syncephalastrum) separated from each other and species within the genera were clustered together and with that of reference sequences with appreciable bootstrap values that validate reliable grouping. Bootstrap values are dependable measures of phylogenetic accuracy and higher values are likely to indicate reliable groups (Hillis \& Bull, 1993). A broad pathogenic and genetic diversity was detected among isolates of Fusarium oxysporum f. sp. cepae restriction digestions of IGS regions of rDNA classified the isolates from Turkey and Colorado into 13 groups (Bayraktar, Türkkan, \& Dolar, 2010; Mess et al., 1999) suggested that $F$. oxysporum f. sp. lycopersici is a polyphyletic taxon. Stewart, Kim, James, Dumroese and Klopfenstein (2006) carried out molecular characterization of morphologically undistinguished isolates of Fusarium. sp., F. oxysporum and F. commune isolates from a conifer nursery using AFLP and ITS rDNA sequencing, mitochondrial rDNA and nuclear translation elongation factor $1-\alpha$. Each isolates had a unique RFLP phenotype.

Out of various regions of rDNA, the ITS and intergenic spacer (IGS) of the nuclear rDNA repeat units have been reported to be evolved fast and may vary among species within a genus or among populations and hence can be used for phylogenetic studies at various taxonomic levels. Molecular phylogenetic analysis has helped to clarify ubiquitous in traditional classification systems of Fusarium species by ITS marker Datta, Choudhary, Shamim, Singh and Dhar (2011) performed molecular diversity analysis in Indian isolates of Fusarium oxysporum f. sp. lentis insighting wilt disease in lentil and reported $77.14 \%$ polymorphism using RAPD. Three molecular markers revealed varying degree of genetic diversity in the selected isolates ranging from $54 \%$ in case of RAPD and up to $35 \%$ with ITS markers.
Llorens et al. (2006) characterized Fusarium species isolates by PCR-RFLP analysis of the intergenic spacer region of rRNA gene (rDNA). They reported that the haplotypes obtained with six restriction enzymes permitted to discern the six assayed Fusarium species and claimed it as a rapid and suitable methodology that allows closely related strains and to estimate the genetic relationship between the groups Chehri, Salleh, Yli-Mattila, Reddy and Abbasi (2011) molecularly characterized pathogenic Fusarium species of cucurbits. They reported that PCR-ITS-RFLP method is simple and rapid procedure for the differentiation of $\mathrm{Fusa}$ rium strains at species level.

Bayraktar (2010) studied the genetic diversity in $F$. oxysporum f. sp. cepae causing basal plate rot on onion, using RAPD markers. The cluster analysis revealed distinct lineages at $65 \%$ similarity. The Nei's genetic distances supported populations grouping according to the geographic regions and 11.4 $\%$ of total genetic diversity (GST) attributed to differentiation among the geographical locations. AMOVA confirmed that there were low genetic differences among populations. Their results suggest that RAPD-PCR is a useful method for analyzing genetic variation within and between populations of Fusarium oxysporum f. sp. cepae.

The AMOVA revealed $100 \%$ variation within population indicating that the total proportion of variability exists within host as compared to different hosts signifying that root pathogens of arid legumes are not host specific in nature. The estimates of Nei's genetic distance and identity between the populations provided a better understanding of genetic relationships. The low GST of 2.0170 among all the populations revealed little evidence for geographical subdivision among four populations. The results of molecular analyses clearly indicates that the out of the four populations of arid legumes, the genetic diversity of root pathogen isolates of population four (moth bean) was the richest. Similarly, low levels of genetic differentiation among geographic populations and high genetic variability have been reported 
on asexually reproducing fungi such as $F$. oxysporum f. sp. vasinfectum (Wang et al., 2006).

The diversity analysis based on DNA sequence polymorphisms existing within highly conserved regions of the nuclear ribosomal DNA, such as the internal transcribed spacer or the intergenic spacer region (Edel, Steinberg, Gautheron, Recorbet, \& Alabouvette, 2000). Zaccardelli, Vitale, Luongo, Merighi, \& Corazza (2008) performed molecular and morphological characterization of Fusarium solani isolates based on host range tests. F. solani were subdivided into different formae speciales and varieties while DNA sequence of 28S rDNA, ITS-rDNA and elongation factor (EF-1 $\alpha$ ) distinguished $F$. solani complex in 50 subspecific lineages.

The documented 'Fungi of India' records of fungi are mostly reported with identifications based on microscopic characteristics following traditional and obsolete keys of classification. Fungi reported herein were identified on the basis of both morphological and nuclear rDNA analysis. The available 'Fungi of India' records and internet searches revealed that Fusarium solani in India as pathogen on leguminous crop was first reported causing root rot of pea (Sen, Lal, \& Majumdar, 1970) and on guar (Satyaprasad \& Ramarao, 1981).

Neocosmospora vasinfecta, from rhizosphere of peanut (Arachis hypogaea L.), as a pathogen of new wild disease of horse gram in India, was first reported by Mishra (1988). $N$. vasinfecta has a wide distribution in tropical and temperate regions and is commonly associated with roots of leguminous crops and has been isolated from soil. $N$. vasinfecta an incident of wilt of Clusterbean have been reported by Patel, Patel, Desai and Khandar (1998). $N$. vasinfecta associated with the root rot complexes of peanuts has been reported in Vietnam (Dau et al., 2010) and China (Huang, Chen, \& Chung, 1992). Cornely et al. (2001) reported $N$. vasinfecta as human pathogenic fungi in a patient with acute non lymphocytic leukemia on the basis of $5.8 \mathrm{~S}$ nuclear rDNA region. They reported SNP's at two nucleotide positions and on insertion of a single base pair.
The root pathogens of the arid legumes were found neither restricted to a geographical location and nor were host specific in nature. A high degree of nucleotide variations in the nuclear rDNA ITS region allowed separation of different genera and species within the genera clustered together and with that of reference sequences validating reliable grouping. We report association of several fungi for the first time as pathogens causing root diseases in arid legumes. Precisely, F. solani wilt in cowpea and seedling rot in moth bean, $F$. oxysporum wilt in moth bean, $F$. acutatum damping off in cowpea and Clusterbean, Fusarium sp. seedling rot in clusterbean, Neocosmospora striata root rot in cowpea and wilt in Clusterbean and $S$. monosporum root rot in Clusterbean. The present findings reveal a complete spectrum of major root pathogens associated with the arid legume and warrant concerted research towards effective management of these pathogens.

\section{ACKNOWLEDGMENTS}

The authors are thankful to the Director, Central Arid Zone Research Institute, Jodhpur for providing necessary laboratory and field facilities. First author is grateful to the University Grants Commission for providing financial assistance in the form of fellowship to carry out this study.

\section{RESUMEN}

Diagnóstico molecular y la variabilidad genética intraespecífica de patógenos de raíces en leguminosas resistentes a sequías del oeste de Rajasthan, India. La producción de leguminosas resistentes a sequías como Cyamopsis tetragonoloba, Vigna unguiculata, Vigna aconitifolia y Macrotyloma uniflorum, puede permanecer inactiva durante décadas debido a su alta susceptibilidad a enfermedades en las raíces. Además, hay información limitada relacionada con el diagnóstico molecular y la variabilidad genética intraespecífica de patógenos de raíces en estas leguminosas resistentes a sequías. Para contribuir en esta área, evaluamos un total de 52 extractos de 88 raíces infectadas con patógenos fúngicos en los distritos de Jodhpur, Jaipur y Bikaner de Rajastán. Las muestras de raíces infectadas se analizaron siguiendo los métodos estándar de microbiología para extracción y purificación 
de hongos y para estudios genéticos. Independientemente del sitio donde se recolectaron las muestras contaminadas, todos los extractos patógenicos se agruparon en dendrogramas RAPD en cada uno de sus respectivos géneros. El filograma, basado en alineamiento de secuencias múltiples reveló que distintos géneros (Fusarium, Neocosmospora y Syncephalastrum) separados entre ellos y especies del mismo género se agrupan con sus secuencias de referencia con valores de bootstrap significativos. De cada 20 extractos representantes de cada agrupamiento y todos los grupos externos secuenciados, ocho fueron identificados molecularmente como Neocosmospora vasinfecta, dos como Fusarium acutatum, una como Syncephalastrum monosporum, una como Fusarium oxysporum y una como Fusarium. Los patógenos de estas leguminosas resistentes a sequías no están restringidos por la localidad ni por un hospedero específico. Fusarium solani que marchita el frijol de vaca y pudre la semilla de Vigna aconitifolia, F. oxysporum que marchita a Vigna aconitifolia, F. acutatum que marchita a Vigna unguiculata y Cyamopsis tetragonoloba, Fusarium sp. que pudre la semilla de Cyamopsis tetragonoloba, Neocosmospora striata que pudre la raíz de Vigna unguiculata y marchita a Cyamopsis tetragonoloba y, Syncephalastrum monosporum que pudre la raíz en Cyamopsis tetragonoloba, fueron identificados molecularmente como nuevos registros de patógenos fúngicos que causan daños en las raíces de leguminosas resistentes a sequías.

Palabras clave: RAPD, ITS, Fusarium, Neocosmospora, Syncephalastrum.

\section{REFERENCES}

Aigbe, S. O., \& Fawole, B. (2010). An efficient laboratory screening method for Fusarium oxysporum of cowpea. Nigerian Annals of Natural Sciences, 10(1), 53-59.

Barnett, H. L., \& Hunter, B. B. (1990). Illustrated genera of imperfect fungi. Third edition. Minneapolis, Minnesota: Burgess Publishing Company.

Bayraktar, H. (2010). Genetic diversity and population structure of Fusarium oxysporum f. sp. cepae, the causal agent of Fusarium basal plate rot on onion, using RAPD markers. Journal of Agricultural Sciences, 16, 139.

Bayraktar, H., Türkkan, M., \& Dolar, F. S. (2010). Characterization of Fusarium oxysporum f. sp. cepae from onion in Turkey based on vegetative compatibility and rDNA RFLP analysis. Journal of Phytopathology, 158, 691-697.

Birren, B., \& Lai, E. (1993). Pulsed field gel electrophoresis: a practical guide. San Diego: Academic Press.
Brayford, D. (1989). Progress in the study of Fusarium and some related genera. Journal of Applied Bacteriology, 67(1), 475-605.

Chehri, K., Salleh, B., Yli-Mattila, T., Reddy, K. R. N., \& Abbasi, S. (2011). Molecular characterization of pathogenic Fusarium species in cucurbit plants from Kermanshah province. Iran Saudi Journal of Biological Sciences, 18(4), 341-351.

Cornely, O. A., Chemnitz, J., Brochhagen, H. G., Lemmer, K., Schütt, H., Söhngen, D., Staib, P., Wickenhauser, C., Diehl, V., \& Tintelnot, K. (2001). Disseminated Neocosmospora vasinfecta infection in a patient with acute nonlymphocytic leukemia. Emerging Infectious Diseases, 7(1), 149-15.

Datta, S., Choudhary, R. G., Shamim, M. D., Singh, R. K., \& Dhar, V. (2011). Molecular diversity in Indian isolates of Fusarium oxysporum f.sp. lentis inciting wilt disease in lentil (Lens culinaris Medik). African Journal of Biotechnology, 10(38), 7314-7323.

Dau, V. T., Pham, L. T., Luong, T. M., Huynh, L. M. T., Tran, N. T., Ho, T. D., Hoang, H. M. T., Phan, H. T. \& Burgess, L. W. (2010). First report of Neocosmospora vasinfecta associated with the root rot complex of peanuts in Vietnam. Australasian Plant Disease Note, 5, 79-81.

Edel, V., Steinberg, C., Gautheron, N., Recorbet, G., \& Alabouvette, C. (2000). Genetic diversity of Fusarium oxysporum populations isolated from different soils in France. FEMS Microbiology Ecology, 36, 61-71.

Gargouri, S., Bernier, L., Hajlaoui, M. R., \& Marrakchi, M. (2003). Genetic variability and population structure of the wheat foot rot fungus, Fusarium culmorum, in Tunisia. European Journal of Plant Pathology, 109, 807-815.

Gautam, R., Singh, S. K., \& Sharma, V. (2013). RAPD and nuclear rDNA ITS polymorphism within Macrophomina phaseolina isolated from arid legumes of western Rajasthan. Proceedings of the National Academy of Sciences, India Section B: Biological Sciences, 84(1), 171-181.

Hillis, D. M., \& Bull, J. J. (1993). An empirical test of bootstrapping as a method for assessing confidence in phylogenetic analysis. Systematic Biology, 42(2), 182-192.

Huang, J. W., Chen, S. S., \& Chung, W. C. (1992). Neocosmospora foot rot of peanut in Taiwan. Plant Pathology Bulletin, 1, 203-205.

Ibrahim, G., \& Nirenberg, H. I. (2000). Recent studies on Fusarium vascular wilt of cotton at the Federal Biological Center for Agricultural and Forstery (BBA), Berlin. Mitt Biol BundAnst Ld.- u. Forstwirtsch H, $377,87-88$ 
Jamil, F. F., Sarwar, N., Sarwar, M., Khan, J. A., Geistlinger, J., \& Kahl, G. (2000). Genetic and pathogenic diversity within Ascochyta rabiei (Pass.) Lab. populations in Pakistan causing blight of chickpea (Cicer arietinum L.). Physiological and Molecular Plant Pathology, 57, 243-257.

Jana, T. K., Sharma, T. R., Prasad, R. D., \& Arora, D. K. (2003). Molecular characterization of Macrophomina phaseolina and Fusarium species by using a single primer RAPD technique. Microbiological Research, $158,249-57$.

Llorens, A., Hinojo, M. J., Mateo, R., González-Jaén, M. T., Valle-Algarra, F. M., Logrieco, A., \& Jiménez, M. (2006). Characterization of Fusarium spp. isolates by PCR-RFLP analysis of the intergenic spacer region of the rRNA gene (rDNA). International journal of Food Microbiology, 106(3), 297-306.

Mes, J. J., Weststeijn, E. A., Herlaar, F., Lambalk, J. J. M., Wijbrandi, J., Haring, M. A., \& Cornelissen, B. J. C. (1999). Biological and molecular characterization of Fusarium oxysporum $\mathrm{f}$. sp. lycopersici divides race 1 isolates into separate virulence groups. Phytopatho$\log y, 89,156-160$

Mishra, D. (1988). A new wild disease of horse gram in India. Current Science, 57, 898.

Narayanasamy, P. (2001). Plant Pathogen detection and disease diagnosis. New York, USA.: Marcel Dekker, Inc.

Nei, M. (1973). Analysis of gene diversity in subdivided populations. Proceedings of the National Academy of Sciences, USA, 70, 3321-3323.

Patel, D. S., Patel, S. I., Desai, B. G., \& Khandar, R. R. (1998). Neocosmospora vasinfecta an incitant of wilt of clusterbean. Indian Phytopathology, 51(3), 305.

Pietro, A. D., Madrid, M. P., Caracuel, Z., Jarana, J. D., \& Roncero, M. I. G. (2003). Fusarium oxysporum: exploring the molecular arsenal of a vascular wilt fungus. Molecular Plant Pathology, 4(5), 315-25.
Riveros, F., Munoz, G., Gonzalez, L., Rojas, A. M., \& Hinrichsen, P. (2001). Comparison between DNA and morphological analysis for identification of Fusarium species isolated from muskmelon (Cucumis melo L.). Agriculture Tecnica, 61(3), 281-293.

Rohlf, F. J. (1997). NTSYS pc: Numerical taxonomy and multivariate analysis system version $2.02 \mathrm{~h}$. Exeter Software, New York.

Sambrook, J., Fritsch, E. F., \& Maniatis, T. (1989). Molecular cloning: a laboratory manual, 2nd edn. Plainview: Cold Spring Harbor Laboratory Press.

Satyaprasad, K., \& Ramarao, P. (1981). Root rot of guar caused by Fusarium solani. Indian Phytopathology, 34, 523-524.

Sen, B., Lal, S. P., \& Majumdar, M. (1970). Fusarium root rot of pea. Indian Phytopathology, 23, 727-728.

Sharma, G., Verma, H. N., \& Sharma, R. (2013). RAPD Analysis to Study Metagenome Diversity in Soil Microbial Community of Arid Zone Plants. Proceedings of the National Academy of Sciences, India Section B: Biological Sciences, 83, 135-139.

Stewart, J. E., Kim, M. S., James, R. L., Dumroese, R. K., \& Klopfenstein, N. B. (2006). Molecular characterization of Fusarium oxysporum and Fusarium commune isolates from a conifer nursery. Phytopathology, $96,1124-1133$

Wang, B., Brubaker, C. L., Tate, W., Woods, M. J., Matheson, B. A., \& Burdon, J. J. (2006). Genetic variation and population structure of Fusarium oxysporum f. sp. vasinfectum in Australia. Plant Pathology, $55,746-755$.

Zaccardelli, M., Vitale, S., Luongo, L., Merighi, M., \& Corazza, L. (2008). Morphological and molecular characterization of Fusarium solani isolates. Journal of Phytopathology, 156(9), 534-541. 